\title{
Dyslipidemia in adults and genetic polymorphism in the mevalonate kinase gene, a
}

\section{systematic review}

\author{
Dislipidemia em adultos e polimorfismo no gene da mevalonato quinase, uma revisão sistemática \\ Dislipidemia en adultos y polimorfismo genético en el gen mevalonato cinasa, una revisión \\ sistemática
}

Received: 06/18/2021 | Reviewed: 06/26/2021 | Accept: 07/01/2021 | Published: 07/14/2021

\author{
Marcelo Cichocki \\ ORCID: https://orcid.org/0000-0003-1923-1928 \\ Universidade Norte do Paraná, Brazil \\ E-mail: marcelocichocki@yahoo.com.br \\ Regina Célia Poli-Frederico \\ ORCID: https://orcid.org/0000-0003-4631-4606 \\ Universidade Norte do Paraná, Brazil \\ Pontifícia Universidade Católica do Paraná, Brazil \\ E-mail: reginafrederico@yahoo.com.br
}

\begin{abstract}
The presence of mutations in dyslipidemia-related genes is of great importance for the outcome of procedures on patients with elevated levels of HDL cholesterol. This systematic review aims to describe the genetic variants in the mevalonate kinase genes in adults with dyslipidemia. A systematic search of the following databases was conducted: Scopus, Web of Science, Google Scholar and Bireme, using the keywords: "Mevalonate Kinase Gene", "Dyslipidemia", "Genetic Polymorphism", linked using the term "AND". The inclusion criteria consisted of articles published between 2008 and 2018, written in Portuguese or English, while the exclusion criteria were the removal of duplicated articles, books, theses and bibliographic reviews, tests not conducted on humans, tests conducted on children and other genes evaluated. The articles listed in this review demonstrate the role of the genetic polymorphism of the mevalonate-kinase gene $(M V K)$ in an adult population. A comparison of results from different studies is often complicated because of the diverse study variables such as: tests used, population studied. The studies described in this review demonstrated that there is an association between genetic profiles and dyslipidemia. Many studies have shown that, besides the external factors and individuals' behavioral habits, the presence of mutations in the mevalonate kinase gene is associated with dyslipidemia.
\end{abstract}

Keywords: Mevalonate kinase; Genetic polymorphism; Dyslipidemia; Adults.

\section{Resumo}

A presença de mutações em genes relacionados à dislipidemia tem grande relevância no resultado de condutas em pacientes com níveis de colesterol HDL alterados. O objetivo desta revisão sistemática foi descrever as variantes genéticas no gene mevalonato-quinase presentes em adultos com dislipidemia. Foi realizada uma busca sistemática nas bases de dados: Scopus, Web of Science, Google Scholar e Bireme; utilizando as seguintes palavras-chave: "Gene Mevalonato Quinase", "Dyslipidemia", "Genetic Polymorphism", foi associado o termo "AND". Os critérios de inclusão foram artigos publicados entre 2008 e 2018, escritos na língua portuguesa ou inglesa e os de exclusão foram a retirada de artigos duplicados, livros, teses e revisões bibliográficas, testes não realizados em humanos, testes realizados em crianças e outros genes avaliados. Os artigos relacionados nesta revisão demonstram o papel do polimorfismo genético do gene mevalonato-quinase $(M V K)$ em população adulta, a comparação de resultados de diferentes pesquisas muitas vezes é dificultado por apresentarem variação em diversas variáveis de estudo, tais como, testes utilizados, população estudada. Os estudos descritos nesta revisão demonstraram que existe associação entre perfis genéticos e dislipidemia. Muito estudos demonstraram que além dos fatores externos e hábitos comportamentais dos indivíduos, a presença de mutações no gene da mevalonato quinase está associada a dislipidemia.

Palavras-chave: Mevalonato quinase; Polimorfismo genético; Dislipidemia; Adultos.

\section{Resumen}

La presencia de mutaciones en genes relacionados con la dislipidemia tiene gran relevancia en el resultado de procedimientos en pacientes con niveles alterados de colesterol HDL. El objetivo de esta revisión sistemática fue describir las variantes genéticas en el gen de la mevalonato quinasa presentes en adultos con dislipidemia. Métodos: Se realizó una búsqueda sistemática en las bases de datos: Scopus, Web of Science, Google Scholar y Bireme; utilizando las siguientes palabras clave: "Gen Mevalonato Quinasa", "Dislipidemia", "Polimorfismo genético", se ha 
asociado el término "Y". Los criterios de inclusión fueron artículos publicados entre 2008 y 2018, escritos en portugués o inglés y los criterios de exclusión fueron la eliminación de artículos duplicados, libros, tesis y revisiones bibliográficas, pruebas no realizadas en humanos, pruebas realizadas en niños y otros genes evaluados. Los artículos enumerados en esta revisión demuestran el papel del polimorfismo genético del gen de la mevalonato quinasa (MVK) en una población adulta, la comparación de resultados de diferentes investigaciones suele ser difícil porque presentan variación en varias variables de estudio, como las pruebas. población utilizada, estudiada. Los estudios descritos en esta revisión demostraron que existe una asociación entre los perfiles genéticos y la dislipidemia. Numerosos estudios han demostrado que, además de los factores externos y los hábitos de comportamiento de los individuos, la presencia de mutaciones en el gen de la mevalonato quinasa se asocia con la dislipidemia.

Palabras clave: Mevalonato quinasa; Polimorfismo genético; Dislipidemia; Adultos.

\section{Introduction}

The mevalonate kinase gene, located in chromosome 12, encodes the mevalonate kinase (MVK) enzyme which is essential for the biosynthesis of cholesterol, exerting an influence over the metabolism of HDL cholesterol (L Miao et al., 2017) The symptoms of the modification of the mevalonate kinase function may manifest as hyperimmunoglobulinemia, which is associated with low levels of HDL, although it can be associated with Periodic Fever Syndrome and, when present in infancy to a severe degree, may lead to death (Browne \& Timson, 2015). The presence of environmental factors has an influence on the appearance of particular symptoms. For example, the symptoms of individuals who have a deficiency in this enzyme are worse at low temperatures (Houten et al., 2002).

The monitoring of the plasmatic levels of cholesterol, evaluation and indications of lifestyle habits with a history of coronary heart disease, should be evaluated in conjunction with the molecular analysis of genes that induce alterations that are not modified by external factors (Sarzynski et al., 2011). Accordingly, genes related to the modulation of HDL cholesterol, such as the mevalonate kinase gene, should be determined for an evaluation of the risk of dyslipidemia associated with coronary heart disease (Sun et al., 2016).

The aim of this review is to present studies which compare external factors with the determination of mutations in the mevalonate kinase gene, in patients with dyslipidemia, by way of a systematic review.

\section{Methodology}

For the selection of the scientific articles, four electronic databases were queried: Scopus, Web of Science, Google Scholar and Bireme, conducted in April 2020.

For the selection of the articles, the following keywords were employed: "Mevalonate Kinase Gene", "Dyslipidemia", "Genetic Polymorphism", the terms being linked using the word "AND". The distribution of the results is exhibited in Figure 1. 
Figure 1. Flowchart of the triage of the articles selected for the present systematic review.

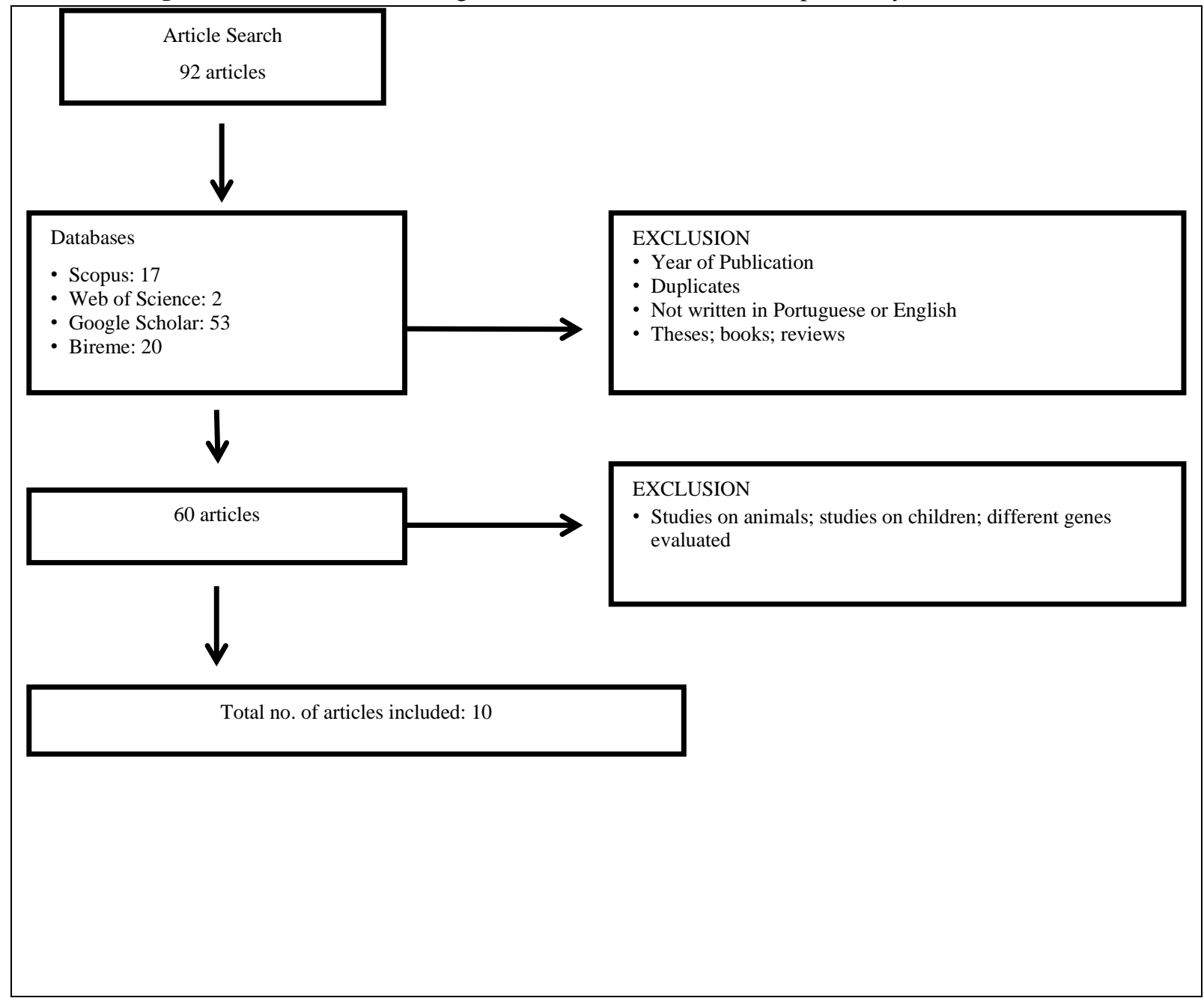

Source: Authors.

The inclusion criteria were defined as follows: the articles must have been published between January 2008 and December 2018 and written in Portuguese or English. Following this initial article triage, they were submitted for reading by two independent reviewers who selected the references in three stages: analysis of titles, abstracts and complete texts. The exclusion criteria were: removal of duplicate articles, books, theses and bibliographic reviews of related subjects. For the reading of the abstracts, the exclusion criteria were once again employed, eliminating articles that included tests not performed on humans, tests conducted on children and an evaluation of different genes.

Given this initial evaluation, the articles were submitted for a full-text reading, from which the data were extracted for the details of this review.

\section{Results}

The articles listed in this review demonstrate the role of the genetic polymorphism of the mevalonate kinase (MVK) gene in an adult population. The comparison of results from different studies is often complicated due to the variability of the diverse variables in the study, such as: tests used, population studied (men vs. women vs. children vs. those with a history of dyslipidemia; among others). In addition to these variables, those related to lifestyle and dietary habits also have an influence on results. 


\section{Discussion}

The V377I genetic variant in the mevalonate kinase gene leads to two distinct forms: Hyperimmunoglobulinemia D and Periodic Fever, the latter being characterized by a fever with inflammatory symptoms which may be mild or severe(Messer et al., 2016).

(Sun et al., 2016) found that alterations to genes $M V K, M M A B$ and $K C T D 10$ impact on the risk for dyslipidemia and coronary heart disease. Figuring among the associated alleles are rs11067233 in the gene $M M A B$, rs11066782 and rs11613718 in the gene KCTD10. It should be stressed that this study was performed on a Chinese population and this has to be taken into account as differences exist between ethnic groups. $M V K$ and $M M A B$ are responsible for controlling cholesterol while KCTD10 is linked to obesity, diabetes and atherosclerosis.

Studies conducted on two distinct ethnic groups in China produced interesting results when genetic factors were taken into account. Among other characteristics, these groups exhibited dietary habits, in marriage within the same ethnic group. The frequency of alleles that encode the mutations in the mevalonate kinase gene was different between the Maonan and Han groups, with rs3759387, rs877710, rs7134594 and rs9593 being detected in the two groups (L Miao et al., 2017). In different genetic groups, these alleles point to a greater risk of coronary heart disease and cerebral ischemia (Liu Miao et al., 2017).

Some studies have reported that different levels of mevalonate kinase are found in different tissues, however it was ascertained that, in the presence of allele rs2287218, it suggests a predisposition to coronary heart disease and ischemic cerebral vascular accident (Wang et al., 2018).

European individuals homozygous for the mutation in the mevalonate kinase (V377I) are asymptomatic, while other individuals with the same mutation may present with severe alterations (Moura, Tricarico, Coelho, \& Crovella, 2015).

(Sarzynski et al., 2011), in their evaluation of the genetic profiles of patients subjected to bariatric surgery, found that the variations in the following loci of the studied genes: ABCA1, APOA5, CETP, GALNT2, LIPC, LIPG, LPL and MMAB / $M V K$, contribute significantly to the plasmatic levels of HDL-C in obese individuals, and that the associations persist even after considerable weight loss resulting from the bariatric surgery. However, they are not associated with alterations induced by surgery at HDL-C levels.

In the study conducted by (Fogarty, Xiao, Prokunina-Olsson, Scott, \& Mohlke, 2010), the relative expression of the SNP allele transcription factors was investigated in 5 genes, using heterozygous, human hepatocyte cells for the genetic variants.

Variant rs7298565 of the gene MMAB (methylmalonic aciduria cblB type) features prominently, producing a regulatory effect to increase the levels of MMAB and reduce the levels of HDL-C, however, as far as the MVK gene is concerned, no significant differences were observed in the imbalance of allele-specific expression (Fogarty et al., 2010).

Junyent et al. (2009) concluded that the association of genetic variations in the three main genes involved in the synthesis of cholesterol (KCDTD10 i5642G, MVK i851G and S52NG and MMAB 3U3527G), interact with the concentration of cholesterol in the plasma. The authors report that it is difficult to compare different ethnic groups, ages, sexes, dietary habits, since all these factors have an influence on the levels of cholesterol and the risk of disease related to the increase in the blood plasma (Junyent et al., 2009; Miao et al., 2017).

In general, the majority of epidemiological studies only take into account individuals' normal external factors compared to the levels of cholesterol in the plasma as well as the risk of developing coronary heart disease, however it can be seen from these articles that genetic factors do influence these factors. Accordingly, in addition to eating and smoking habits, they must also be associated with the amount and intensity of physical exercise to which these individuals are accustomed. Another important factor lies in the drug therapy since, when genetic factors are present, therapies should be reviewed to tailor them to each individual. 


\section{Conclusions}

The studies described in this review show that there is an association between genetic profiles and dyslipidemia. Many studies have shown that, besides the external factors and behavioral habits of individuals, the presence of mutations in the mevalonate-kinase gene is associated with dyslipidemia. Further studies evaluating the genetic profile of other populations must be performed in order to acquire a deeper understanding of the implications of this mutation. The role of physical activity in the population of diverse age groups should also be evaluated. Further studies are needed to confirm the present findings.

\section{Declaration of the contribution of the authors:}

All authors contributed to the study conception and design. Material preparation, data collection and analysis were performed by MC. The first draft of the manuscript was written by RCPF and all authors commented on previous versions of the manuscript. All authors read and approved the final manuscript.

\section{References}

Browne, C., \& Timson, D. J. (2015). In Silico Prediction of the Effects of Mutations in the Human Mevalonate Kinase Gene: Towards a Predictive Framework for Mevalonate Kinase Deficiency. Annals of Human Genetics, 79(6), 451-459. https://doi.org/10.1111/ahg.12126

Fogarty, M. P., Xiao, R., Prokunina-Olsson, L., Scott, L. J., \& Mohlke, K. L. (2010). Allelic expression imbalance at high-density lipoprotein cholesterol locus MMAB-MVK. Human Molecular Genetics, 19(10), 1921-1929. https://doi.org/10.1093/hmg/ddq067

Houten, S. M., Frenkel, J., Rijkers, G. T., Wanders, R. J. A., Kuis, W., \& Waterham, H. R. (2002). Temperature dependence of mutant mevalonate kinase activity as a pathogenic factor in hyper-IgD and periodic fever syndrome. Human Molecular Genetics, 11(25), 3115-3124. https://doi.org/10.1093/hmg/11.25.3115

Junyent, M., Parnell, L. D., Lai, C.-Q., Lee, Y.-C., Smith, C. E., Arnett, D. K., \& Ordovás, J. M. (2009). Novel variants at KCTD10, MVK, and MMAB genes interact with dietary carbohydrates to modulate HDL-cholesterol concentrations in the Genetics of Lipid Lowering Drugs and Diet Network Study. The American Journal of Clinical Nutrition, 90(3), 686-694. https://doi.org/10.3945/ajcn.2009.27738

Messer, L., Alsaleh, G., Georgel, P., Carapito, R., Waterham, H. R., Dali-Youcef, N., \& Sibilia, J. (2016). Homozygosity for the V377I mutation in mevalonate kinase causes distinct clinical phenotypes in two sibs with hyperimmunoglobulinaemia $\mathrm{D}$ and periodic fever syndrome (HIDS). RMD Open, 2(1). https://doi.org/10.1136/rmdopen-2015-000196

Miao, L, Yin, R.-X., Pan, S.-L., Yang, S., Yang, D.-Z., \& Lin, W.-X. (2017). Association between the MVK and MMAB polymorphisms and serum lipid levels. Oncotarget, 8(41), 70378-70393. https://doi.org/10.18632/oncotarget.19707

Miao, Liu, Yin, R.-X., Huang, F., Chen, W.-X., Cao, X.-L., \& Wu, J.-Z. (2017). The effect of $M V K-M M A B$ variants, their haplotypes and GxE interactions on serum lipid levels and the risk of coronary heart disease and ischemic stroke. Oncotarget, 8(42). https://doi.org/10.18632/oncotarget.20349

Moura, R., Tricarico, P. M., Coelho, A. V. C., \& Crovella, S. (2015). GRID2 a novel gene possibly associated with mevalonate kinase deficiency. Rheumatology International, 35(4), 657-659.

Sarzynski, M. A., Jacobson, P., Rankinen, T., Carlsson, B., Sjöström, L., Carlsson, L. M. S., \& Bouchard, C. (2011). Association of GWAS-based candidate genes with HDL-cholesterol levels before and after bariatric surgery in the Swedish obese subjects study. The Journal of Clinical Endocrinology \& Metabolism, 96(6), E953-E957.

Sun, J., Qian, Y., Jiang, Y., Chen, J., Dai, J., Jin, G., \& Shen, H. (2016). Association of KCTD10, MVK, and MMAB polymorphisms with dyslipidemia and coronary heart disease in Han Chinese population. Lipids in Health and Disease, 15(1), 171. https://doi.org/10.1186/s12944-016-0348-7

Wang, D.-S., Yin, R.-X., Li, K.-G., Lu, L., Su, Y., \& Yan, R.-Q. (2018). Association between the MVK rs2287218 SNP and the risk of coronary heart disease and ischemic stroke: A case-control study. BioScience Trends, 12(4), 403-411. https://doi.org/10.5582/bst.2018.01146 